\title{
Human Processing of Rodents in Patagonia: The Relevance of Historical and Ethnographical Data for Archaeological Interpretations
}

\author{
Analia Andrade* \\ Instituto Patagónico de Ciencias Sociales y Humanas, Argentina
}

*Corresponding author: Analia Andrade, Instituto Patagónico de Ciencias Sociales y Humanas, Argentina.

Received Date: January 17, 2019

Published Date: February 05, 2019

\begin{abstract}
The consumption of small mammals was a widespread practice between indigenous societies worldwide. Modern taphonomic studies carried out upon bone assemblages from archaeological sites in northern Patagonia (Argentina) demonstrate that Caviomorph rodents were also included in the diet of Patagonian populations, both from the steppe and the forests, at least since the Late Holocene. The revision of historical and ethnographical documents written by priests, naturalists and ethnographers during c. XVI-XX allow to corroborate that rodents were intensively exploited in Patagonia, continental and insular. Bones, meat and skin of the animals were employed for diverse purposes, and the gathering activity was guided by women and children.
\end{abstract}

Keywords: Human rodent consumption; Intensive exploitation; Small mammals; Patagonia; Ethnography; Zooarchaeology; Culture and ideology.

\section{Introduction}

The consumption and utilization of rodent species by indigenous societies was documented worldwide through diverse cultural practices, both religious and economic [1-6]. The Olduvai Gorge (1.76 Ma, Tanzania) is the earliest archaeological documentation of hominids micromammals consumption [7]. In the Central Andes, the caviidae Cavia porcellus was domesticated since pre-Columbian times $[8,9]$. and it is included in ritual ceremonies [10,11] Aymara and Quechua populations from the Puna of Argentina, Bolivia and Chile uses the skins of the Abrocoma species, and specimens of Galea musteloides with cranial deformations have been found in tombs suggesting micromammals captivity [12].

While in Patagonia (southern part of South America) the proportions of rodent remains in zooarchaeological contexts are, in many cases, higher than those of other taxa, the role of small mammals in human subsistence was underestimated. The reasons for this underestimation were the preponderance attributed for large and medium sized mammals in human diets, the consideration of rodents as intrusive (and bioturbation agents) into the archaeological sequences and the absence of clear evidences (like cut marks) that could allow to associate them with defined cultural practices. This review discusses the intensity in the exploitation of certain species of rodents in Patagonia. It is argued - based on archaeological, historical and etnographical evidencesthat indigenous societies used this resource integrally since at least the Late Holocene.

\section{Discussion}

Modern taphonomic studies carried out upon small mammals' assemblages from archaeological sites in northern Patagonia allowed to demonstrate the rodent consumption between Patagonian people. For northwestern arid Patagonia, the Caviomorpha species Ctenomys sp., Microcavia australis and possibly also Galea leucoblephara were exploited by huntergatherers since at least 2000 years BP (13, Loncomán Cave CLO, Rio Negro province). The overrepresentation of skull bones and distal elements of the limbs, the high degree of fragmentation in the bone sample, and the defined pattern of thermal alteration, mostly affecting distal segments of tibias, incisors, premaxillaes and mandibles of caviomorpha species, allowed to include them into the list of species exploited by hunter-gatherers from the northern Patagonian steppes. For northeastern arid Patagonia, the consumption of the cricetid rodent Holochilus brasiliensis and Caviidae species was proposed based upon the presence of cut 
marks, tools manufactured on rodent bones and thermal alteration [14]. Specific cut marks related with a careful skinning was observed for the caviidae species Cavia aperea and Galea tixiensis from the Argentinean Pampas [15] suggesting the use of the skin. A pattern similar to the observed for the Loncoman Cave small mammal sequence was obtained for some archaeological sites located in the north-Patagonian Andean forest demonstrating that the rodent consumption was not an exclusive practice of the hunter-gatherer populations from the steppe [16]. Moreover, the consumed species -G. eublepharid, M. australis, Ctenomys haigi, and possibly also C. sociabilis- are not typical components of the forest's fauna, but from un-forested and xeric environments in the near steppe. The presence of those species in the archaeological context raises new hypotheses that are being tested (Andrade, unpublished data) regarding possible changes into the landscape by natural and/or anthropogenic causes, since transport of rodents from the steppe or forest-steppe ecotone is improbable given their small size and the distances involved (20-40km currently, see discussion in 16).

The combination of the taphonomy evidence with historical and ethnographical data allowed to demonstrate that the way in which rodent bones are presented in the archaeological record is closely related with the technique employed to prepare the animals to be consumed. Moreover, rodents were intensively exploited in Patagonia -both for the continental people gününa küne and aonik'enk and for the insular selk'nam- and this practice continued until the last century. Their predilection for rodents was recorded since the first contact episode back to 1520 . For the selk'nam people from northern Tierra del Fuego it became even one of the main food items and considered a delicacy [17]. The historical and ethnographical information comes from documents from c. XVI-XX written by priests, naturalists and ethnographers, who made the first contacts with the Patagonian indigenous societies. Chronicles relate that animals were eviscerated and cooked directly on coals, and in many cases, they left the skin and only the biggest bones were discarded. The combustion traces observed in the extreme of incisors, premaxillae's, mandibles and tibias in the archaeological record agree with this way of cooking. The remaining bones, smaller and weakened by cooking, would be consumed together with the meat and therefore, their representativeness would decrease in the record. An experimental cooking study showed that thermoalteration is restricted to the distal portions due to the retraction of muscles during roasting [18]. For the Atacama Desert (northern Chile), ethnographic and archaeological evidence showed that animals were beheaded before cooking, causing the overrepresentation of heads in the record [19]. An overrepresentation of mandibles, maxillae and isolated molars in some archaeological sites (Central Chile, 20; New Mexico, 21 and South Africa, 2 amongst others) was interpreted as evidence of human discarded activities related with subsistence. This was also regularly observed in some Patagonian archaeological sites (see discussion on 16, 17 and the reference cited therein).

Animals consumed are large, diurnal and fossorial-colonial species because they are conspicuous and predictable in space [20]. Taking advantage of these ecological habits, animals were directly stalked at the entrance of their caves, using a pointed stick for their capture. In addition, this gathering activity was guided by sex and age, and linked with the biological and social reproduction [17]. This task oversaw women and children. In addition to be a food resource, the Ctenomys animals provided raw materials to make manufactures. The skin was used as a cephalic girdle to adjust the neonates (during a lunar cycle), to make clothing (also a female task) and as stored bags to transport colour substances. For the selk'nam people, the mother, after the birth, only can eat Ctenomys skin, bird fat, seafood and vegetables, a period in which meat was prohibited, but not the food product of her own gathering activity. For the Mapuche people -also known as Arucanos- who live in south-central Chile, rodents from the families, Chinchillidae and Octodontidae also constituted an important and common food item -and also for the Spanish conquers during scarcity times (12)showing that inclusion of rodents in prehistoric diets would be a regional pattern.

\section{Conclusion}

The consumption of rodents in Patagonia was a topic of debate between researchers, and previous analyses did not advance to distinguish between cultural and natural depositional agents for the small mammals in the archaeological contexts. The inclusion of taphonomic, historical and ethnographical evidences in the analysis allowed to understand that rodents were an important item in the diet of Patagonian indigenous societies -from the actual territories of Chile and Argentina- and constituted a regular resource for local populations. Not only was the meat employed, but also the skin and bones. The high abundance reported in the chronicles would favor their consumption, but they were chosen for the taste, considered even a delicacy.

\section{Acknowledgement}

Field and laboratory work were funded by CONICET (Consejo Nacional deInvestigaciones Científicas y Técnicas, Argentina) and ANPCyT (Agencia Nacional de Promoción Científica y Tecnológica). María Florencia del Castillo helped with the English version of this manuscript.

\section{Conflict of Interest}

\section{No conflict of interest.}

\section{References}

1. Henshilwood CS (1997) Identifying the collector: evidence for human processing of the cape dune mole-rat, Bathyergus suillus, from Blombos cave, southern cape, South Africa. J Archaeol Sci 24(7): 659-662.

2. Dewar G, Jerardino A (2007) Micromammals: when humans are the hunters. Journal of Taphonomy 5(1): 1-14

3. Rosenfeld S (2008) Delicious guinea pigs: seasonality studies and the use of fat in the pre-Columbian Andean diet. Quat Int 180(1): 127-134.

4. Weissbrod L, Bar-Oz G, Yeshurun R, Weinstein-Evron M (2012) Beyond fast and slow: the mole rat Spalax ehrenbergi (order Rodentia) as a test case for subsistence intensification of complex Natufian foragers in southwest Asia. Quat Int 264(20): 4-16.

5. Shaffer BS (1992) Interpretation of gopher remains from southwestern archaeological assemblages. Am Antiq 57(4): 683-691.

6. Yohe II RM, Newman ME, Schneider JS (1991) Immunological identification of small mammal proteins on aboriginal milling equipment. Am Antiq 56(4): 659-666. 
7. Fernández Jalvo Y, Andrews P, Denys C (1999) Cut marks on small mammals at Olduvai Gorge Bed I. J Human Evol 36(5): 587-589.

8. Spotorno AE, Marín JC, Manríquez G, Valladares JP, Rico E, et al. (2006) Ancient and modern steps during the domestication of guinea pigs (Cavia porcellus L.). J Zool 270: 57-62.

9. Wing E (1986) Domestication of andean mammals. Vuilleumier F, Monasterio M (Eds), High altitude tropical biogeography, Oxford University Press, Oxford, USA, p. 246-264.

10. Bolton R (1979) Guinea pigs, protein, and ritual. Ethnology 18(3): 229252.

11. Sandweiss DH, Wing ES (1997) Ritual rodents: The Guinea pigs of Chincha, Peru. Journal of Field Archaeology 24(1): 47-58.

12. Mann G (1978) Los pequeños mamíferos de Chile. Gayana, Zoología 40: $1-342$.

13. Andrade A (2015) Distinguishing between cultural and natural depositional agents: micromammal taphonomy from the archaeological site Cueva y Paredón Loncomán (Patagonia, Argentina). J Archaeol Sci reports 3: 122-131.

14. Fernández FJ, del Papa L, Moreira GJ, Prates L, De Santis LJM (2011) Small mammal remains recovered from two archaeological sites in the middle and lower Negro River valley (late Holocene, Argentina): taphonomic issues and paleoenvironmental implications. Quat Int 245(1): 135-147.

15. Quintana C (2005) Despiece de microroedores en el Holoceno Tardío de las Sierras de Tandilia (Argentina). Archaeofauna 14: 227-238.

16. Andrade A, Fernandez PM (2017) Rodent consumption by huntergatherers in north Patagonian Andean forests (Argentina): Insights from the small vertebrate taphonomic analysis of two late Holocene archaeological sites. J Archaeol Sci reports 11: 390-399.

17. Andrade A, Boschín MT (2015) Explotación de roedores por las sociedades cazadoras recolectoras de Patagonia durante el Holoceno tardío: de la evidencia arqueológica al registro histórico. Zephyrus 75: 107-124.

18. Medina ME, Teta P, Rivero D (2012) Burning damage and small-mammal human consumption in Quebrada del Real 1 (Córdoba, Argentina): an experimental approach. J Archaeol Sci 39: 737-743.

19. Hesse B (1984) Archaic exploitation of small mammals and birds in northern Chile. Estudios Atacameños 7: 42-61.

20. Simonetti J, Cornejo LE (1991) Archaeological evidence of rodent consumption in Central Chile. Lat Am Antiq 2(1): 92-96. 